\title{
Preliminary Research of Composite Rocket Propellants with hexogen and Titanium Oxide Powder
}

\author{
Vesna Rodic ${ }^{1)}$ \\ Marica Bogosavljević ${ }^{1)}$ \\ Aleksandar Milojkovic ${ }^{1)}$ \\ Slavko Mijatov ${ }^{1)}$
}

\begin{abstract}
Composite solid propellants based on ammonium perchlorate/hydroxyl-terminated polybutadiene/isophorone dyisocyanate including two levels of hexogen (RDX) are presented in this paper. The mass of RDX increased in relation to oxidant, with constant bimodal fraction ratio. Combustion of the propellants was improved by adding of titanium (IV) oxide powder as stabilizer. Parameters of burning rate laws and apparent viscosity values were determined and compared for the propellants of the same total solid phase. Calculations of thermochemical parameters are also given in this research
\end{abstract}

Key words: composite solid propellant, ammonium perchlorate, hydroxyl-terminated polybutadiene, hexogen, titanium (IV) oxide, ballistic characteristics, thermochemical parameters.

\section{Introduction}

$\mathrm{R}$ OCKETS use the principle of jet propulsion. This is the application of the Newton's Third Law of Motion that 'action and reaction are equal and opposite'. If a fluid is ejected from a vessel through a nozzle at a high velocity, then the force causing it to be ejected results in an equal force in the opposite direction propelling the vessel in a direction which is opposite to the ejecting fluid.

Different classes of solid propellants: composite propellants, double-base (DB), composite modified doublebase propellants, nitramine propellants were developed in order to meet the requirements of various missions in terms of:

- wide range of burn rates $(v)$

- low pressure index $(n)$,

- specific impulse $\left(I_{s p}\right)$, as high as possible, and/or

- smokeless characteristics [1].

Enhanced performance of propellants is the most soughtafter attribute for ambitious research programs in the field of high energy materials.

In the past decades novel molecular structures have been synthesized and a number of them are being developed for the use in rocket propulsion. However, each newly developed energetic material needs years of vigorous field-testing. The investigations on solid propulsion have grown over the years and continue to emerge with attention to safe handling and operation, as well as performance reliability, reproducibility and cost minimization [2].

Different chemical ingredients and their proportions lead to different physical and mechanical properties, combustion characteristics, and performance. Adjusting some of these characteristics often deteriorates the others, so the aim is to form such a formulation that will fulfill as many requirements as possible.

The use of composite solid propellants (CSP) including different ingredients affecting important behaviours during combustion, exploitation and handling, but also the underway preparation procedure, is very widespread. Using two types of particles (aluminium and ammonium perchlorate) maximizes the impulse-density products obtained from the propellants. The basic disadvantages which should be eliminated are smoke (if CSP replaces the DB) and corrosive acidic products and pollution by chlorine-containing combustion.

Research and development efforts have brought an array of nitramines including the following possibilities:

- better energetic performances,

- improved specific impulse

- desired, optimum, steady and non-steady burning characteristics of the propellants,

- greater range for rocket systems,

- smokeless features and noncorrosive combustion products.

Previous research showed that partial substitution of ammonium perchlorate (AP) by cyclotetramethylene tetranitramine (HMX) or cyclotrimethylene trinitramine (RDX) reaches better energetic and smokeless performances of the propellants by increasing specific impulse and reduces the danger of environmental release of hydrogen chloride present in the combustion products into the atmosphere [3]. Because RDX and HMX contain a high concentration of hydrogen atoms, the combustion of nitramine propellants produces low molecular weight gases, and relatively high specific impulses [4]. Therefore nitramines have emerged as alternatives to ammonium perchlorate (AP).

The aim of this paper is to evaluate the influence of hexogen (RDX) on the combustion of composite solid propellants based

\footnotetext{
1) Military Technical Institute (VTI), Ratka Resanovića 1, 11132 Belgrade, SERBIA

Correspondence to: Vesna Rodić; e-mail: springvesna63@gmail.com
} 
on $\mathrm{AP} / \mathrm{RDX}$ mixture in a polybutadiene binder, and estimate if those formulations offer any advantage over commonly used AP - based propellants. The RDX share in the propellant formulations has been altered and each of those compositions has been used to predict the parameters of burning rate law. According to propellant compositions, the thermochemical calculation is also carried out for prediction of parameters, which are necessary for further conclusions about the applicability of the considered nitramine propellants.

\section{Theoretical part}

Many complexities are introduced with heterogeneous propellants containing multiple ingredients, including a completely new set of reactions. Like all solid propellants, a CSP must produce hot gases which create a thrust by expanding in the nozzle, capable of releasing sufficient energy to ensure the grain burning. Oxidizer and metal fuel come in the form of solid powders, incorporated into a binder to give cohesion and homogeneity. However, it is very important to understand the geometry of the propellant (shape of grain) and its effects on the combustion (differences between burning surface and the heat feedback from the flames to the surface) [5].

A solid propellant develops thrust due to discharge of gaseous products of combustion. The burning process in the rocket motor is influenced by the thermodynamic performance values of the propellant, the burning characteristics of the propellant grain, depending on its shape and the pressure influence of the burning rate. The specific impulse is viewed as a key measure of propellant performance. It can be interpreted as the thrust derived per unit weight flow of propellant. It is a theoretical maximum of the mechanical work that can be derived from the adiabatic decomposition of a unit mass of propellant followed by the expansion of the decomposition products into an environment of specified pressure, which is usually near the total vacuum of the outer space. In other words, it is the released enthalpy converted into the kinetic energy of the exhaust jet.

The heat released during the combustion increases the combustion temperature $T_{c}$ which is expressed by:

$$
T_{c}=\Delta H_{r} / c_{p}
$$

where:

- $\Delta H_{r}$ - heat of reaction, $(\mathrm{kJ} / \mathrm{mol})$

- $c_{p}$ - specific heat capacity $(\mathrm{kJ} / \mathrm{mol} \mathrm{K})$.

Specific impulse is also defined as the thrust achieved per unit mass of propellant and is expressed by:

$$
I_{s p}=F \times t / W
$$

where:

- $F$ - thrust (N)

- $t$ - time (s)

- $W$ - mass of propellant, (kg).

The heat of reaction is expressed by:

$$
\Delta H_{r}(T)=\Delta H_{f}(T)_{\text {products }}-\Delta H_{f}(T)_{\text {reactants }}
$$

The heat of formation $\Delta H_{f}$ depends on the bond energies between the atoms of various ingredients used in propellant formulations. To get a combustible temperature as high as possible, one must select reactants with large positive heats of formation and products with large negative heat of formation. The maximum energy output is possible from a material when it contains bonds with bond energies as small as possible and products with bond energies as high as possible [2].

The oxygen required for the combustion can be introduced by chemical reactions or by mechanical incorporation of materials containing bound oxygen.

One of the primary ways of improving the specific impulse of propellants is by increasing enthalpy release and decreasing the average molecular weight of the exhaust gasses to attain more working fluid. In order to achieve this, the propellant should contain sufficient oxygen to maximize the energy release. This is possible when the molecules contain bonds between first row elements, i.e. $\mathrm{C}-\mathrm{N}, \mathrm{N}-\mathrm{O} . \mathrm{N}=\mathrm{O}, \mathrm{N}=\mathrm{N}, \mathrm{N}-\mathrm{F}$ and $\mathrm{O}-\mathrm{N}$ in propellant formulations. The presence of a larger number of such bonds improves the oxygen balance [2].

Oxygen balance $(\mathrm{OB} \%)$ is an expression that is used to indicate the degree to which explosive materials can be oxidized. If an explosive molecule contains just enough oxygen to form carbon dioxide from carbon, water from hydrogen molecules, and all metal oxides from metals with no excess, the molecule has a zero oxygen balance. The molecule with positive oxygen balance contained more oxygen than is needed and molecule with negative oxygen balance contained less oxygen than it needed. In the case of negative oxygen balance the combustion will be incomplete, and a large amount of toxic gases like carbon monoxide will be present. The sensitivity, strength, and brisance of an explosive material are all dependent upon oxygen balance.

The OB is calculated from the empirical formula of a compound in percentage of oxygen required for complete conversion:

$$
\text { OB } \%=\left(-1600 / M_{e x}\right) \times(2 \mathrm{X}+(Y / 2)+M-Z)
$$

where:

- $X$ - number of atoms of carbon,

- $\quad Y$ - number of atoms of hydrogen,

- Z - number of atoms of oxygen, and

- $M$ - number of atoms of metal.

For example in the case of $\operatorname{RDX}\left(\mathrm{C}_{3} \mathrm{H}_{6} \mathrm{~N}_{6} \mathrm{O}_{6}\right)$ :

$$
\text { Molecular weight }=222.1 ; \mathrm{X}=3 ; Y=6 ; Z=6
$$

Therefore,

$$
\begin{gathered}
\text { OB } \%=-1600 / 222.1 \times(6+3-6) \\
\text { OB } \%=-21.6 \%(\text { for RDX })
\end{gathered}
$$

Since experimental testing requires significant financial and material resources, computer simulations of the phenomenon in the rocket motor has been developed. These simulations give preliminary data of rocket propellants energy performance and guidelines for further experimental work. Theoretical energy performance is a useful tool for calculating, comparing and predicting the performance of various rocket systems. By using them, it is easy to obtain the data of average molecular weight of the flame gases, combustion temperature, average ratio of heat capacity, characteristic velocity and specific impulse.

These theoretical analyses are just the simplification of the processes that really happen in the combustion chamber during the passing of gaseous products through rocket motor nozzle, so certain approximate approaches have to be adopted. Most often thermochemical calculations are based on the following approximations:

1. working fluid (combustion products of rocket propellant) is homogenous, 
2. gaseous components of working fluid are subjected to Ideal Gas Law,

3. flow is adiabatic (there is no heat exchange through motor chamber walls),

4. flow is uniform and unchangeable in time; spreading of working fluid is uniform and even, transitional regimes (starting and termination of combustion process) are very short and they can be ignored,

5. gases at the nozzle exit have only axial component of velocity,

6. velocity, pressure, temperature and density are uniformly changed through each section normal to the nozzle axis,

7. there are no losses due to friction, and the influence of the boundary layer is negligible,

8. there are no shock waves and discontinuity in the flow through the nozzle.

The calculation is carried out in two phases:

1. combustion in the rocket motor case: it takes place at a constant pressure and the reactions are carried out very quickly due to high temperature, whereby a chemical equilibrium is established,

2. expansion in the nozzle: the mixture of the combustion products enters the nozzle, and it expands thermodynamically [2].

Most of the thermochemical calculations simulate idealized models of a one-dimensional flow, and therefore, higher values are obtained for the specific impulse than the real values: it should be corrected by the empirical loss factors.

Besides that, in order to obtain better results, it is very important to have propellant components which undergo complete phase transformation during combustion like AP as the most commonly used solid-state oxidizer [6]. This type of oxidizer has the advantage of being completely convertible to gaseous reaction products [7].

AP produces hydrogen chloride $(\mathrm{HCl})$ which increases the average molecular weight. Properties of some other oxidizers are given in Table 1:

Table 1: Properties of some oxidizers [2]

\begin{tabular}{|c|c|c|}
\hline Oxidizer & $\Delta H_{f}(\mathrm{~kJ} / \mathrm{mol})$ & $\mathrm{OB}(\%)$ \\
\hline \hline Hexogen (C3H6N6O6) & 70.63 & $-21.6 \%$ \\
\hline Octogen (C4H8N8O8) & 74.88 & $-21.6 \%$ \\
\hline Ammonium nitrate (NH4NO3) & -365.04 & $+20.0 \%$ \\
\hline Ammonium perchlorate (NH4ClO4) & -296.00 & $+34.0 \%$ \\
\hline
\end{tabular}

Some of the oxidizers have negative heat of formation with a positive oxygen balance. A detailed performance calculation in combination with a binder including favourable characteristics is required before establishing the suitable combination.

On the other hand, nitramines are high-energy-density materials producing high-temperature gaseous products. When any portion of the AP in propellant is replaced with nitramine, an AP-nitramine propellant is formulated [4].

The nitramines are the most recently introduced class of organic nitrate explosives; bigger molecules will give more power because more realisable energy can be packed in the same space. Bigger molecules using the same proportion of elements are more dense because the formation of covalent bonds makes atoms come closer together [2].

RDX, also known as hexogen, shown in Figures 1 and 2, is a very promising ingredient used in rocket propulsion. It has a high degree of stability in storage and is considered one of the most powerful and brisant military high explosives, with a structure similar to that of HMX Some important characteristics of RDX are given in Table 2 [7].

Table 2: Characteristics of RDX

\begin{tabular}{|c|c||}
\hline \multicolumn{2}{|c||}{$\begin{array}{c}\text { Characteristics of cyclo-1,3,5-trimethylene-2,4,6-trinitramine, } \\
\text { RDX, T4 }\end{array}$} \\
\hline \hline Appearance & colorless crystals \\
\hline$M(\mathrm{~kg} / \mathrm{kmol})$ & 222.12 \\
\hline$\Delta H_{f}(\mathrm{~kJ} / \mathrm{kg})$ & +317.98 \\
\hline $\mathrm{OB},(\%)$ & -21.6 \\
\hline Density, $(\mathrm{g} / \mathrm{cm} 3)$ & 1.82 \\
\hline Melting point, $\left({ }^{\circ} \mathrm{C}\right)$ & 204 \\
\hline Impact sensitivity, $(\mathrm{Nm})$ & 7.5 \\
\hline Friction sensitivity, $(\mathrm{N})$ & 120 \\
\hline
\end{tabular}

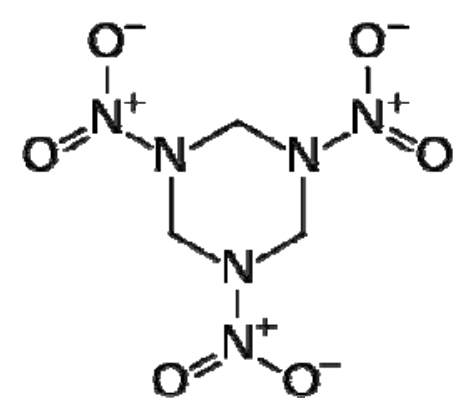

Figure 1. Chemical structure of hexogen (RDX)

RDX is soluble in acetone and sparingly soluble in ether and ethanol. Cyclohexanone, nitrobenzene and glycol are solvents at elevated temperatures. RDX has very low solubility in water and has an extremely low volatility [6]. Its performance properties are only inferior to those of the homologous octogen (HMX).

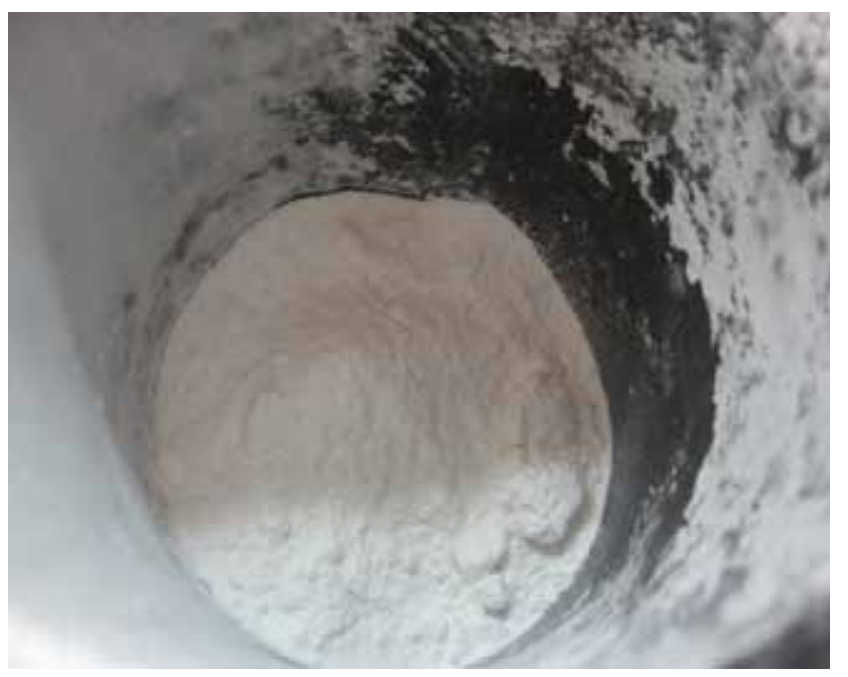

Figure 2. The white powder of RDX

The combustion of RDX is running according to chemical description [8]:

$$
\begin{gathered}
\mathrm{RDX}_{(e)} \stackrel{k_{1}}{\longrightarrow} 3 \mathrm{CH}_{2} \mathrm{O}+3 \mathrm{~N}_{2} \mathrm{O} \\
\mathrm{RDX}_{t e} \stackrel{k_{2}}{\longrightarrow} 3 \mathrm{HCN}+i \mathrm{NO}+3 \mathrm{NO}_{2}+i \mathrm{H}_{2} \mathrm{O}
\end{gathered}
$$

During combustion there is one specific phenomenon: a 
presence of so-called foam layer in the combustion wave structure of RDX, Fig.3.

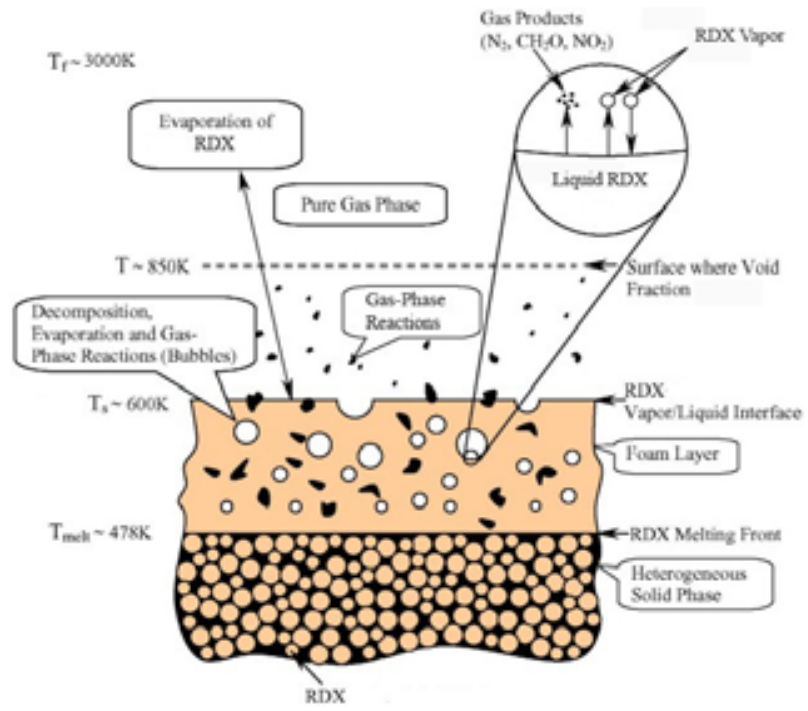

Figure 3. Schematic illustration of foam wave structure

The higher burning rate of RDX propellants, as compared to HMX propellants, is due to the larger heat release from their burning surface [9]. The large gas-phase heat feedback of RDX could be explained by the large temperature gradient near the surface [5].

RDX propellants form a visible, definite liquid layer and during combustion, there is probably little effective reaction contributing to the combustion process below the melt temperature. The melt layer is not directly observable and the melt temperature has not been determined, other than through inferences [10].

The average molecular weight of the combustion products of composite nitramine propellants is lower than that of more conventional AP based CSP. Consequently, the propellant performance is greater than AP propellants at equivalent flame temperatures since propellant performance is inversely proportional to the molecular weight of the exhaust products. Besides, propellants with RDX crystals, Fig.4, tend to have higher densities than AP propellants and, thus, their density impulse is greater, in addition to excellent thermal stability.

However, some disadvantages have been encountered by the substitution of AP with nitramine. These include high burn rate exponents, exponent shifts, low burning rate, and difficulty in tailoring these low burning rates and high pressure exponents and more difficulties to ignite comparing to AP-based composite propellants [11].

The burning rates of RDX, the same as HMX propellants are usually much lower than comparable propellants containing AP [7]. However, for RDX propellants, variations in particle size have minimal effect on changing the burning rate, as can be seen by comparing the burning rate range above with that of AP propellants. In order to increase the burning rate, propellant formulators have turned to additives such as metal catalysts, but the pressure exponent was high and these rates are still below that of AP based propellants. For minimum variation in the thrust or chamber pressure, the pressure exponent and the temperature coefficient should be small [11].

The tailorability of RDX propellants is therefore more limited than that of AP propellants [11]. Anyway, in order to produce a usable propellant formulation, it is necessary to control the burn rate of the propellant, prevent unacceptable performance (pressure that is too high or too low) for the intended purpose of the device.

The instability during the combustion has to be avoided because of many undesirable events, and can be prevented by adding specific additives $[12,13]$. These compounds may have an influence on parameters of all characteristics, especially the ballistic performance and the achievement of the necessary requirements for the propellant.

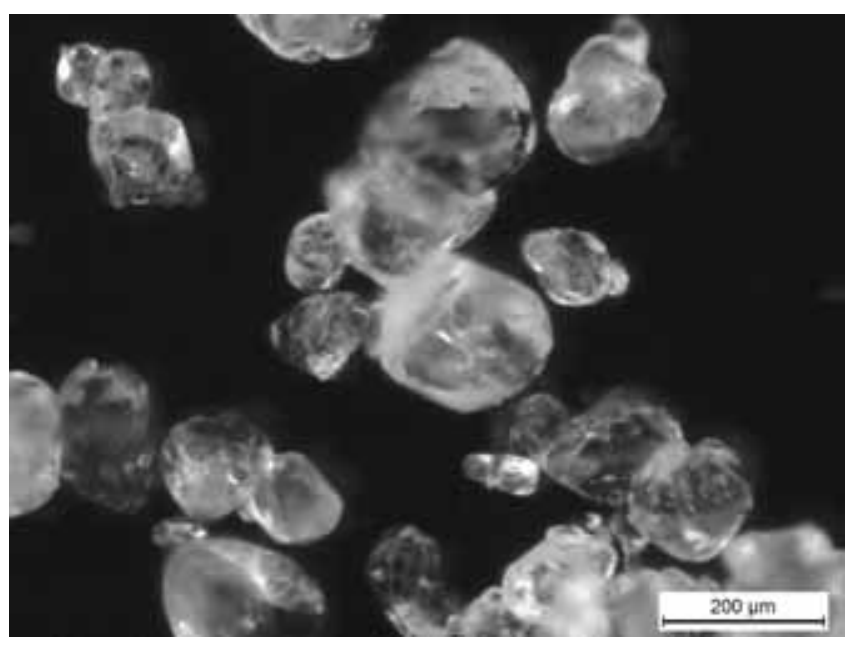

Figure 4. The particles of RDX

It was known that titanium determined parameters of flame stabilization and sensitivity of the flame, which led to the conclusion that titanium was the best stabilizer [3]. One of the refractory oxides, $\mathrm{TiO}_{2}$ is used in this research because of the ability to affect combustion process, and even to form a plateau in the compositions of wide distribution of AP particle sizes $[14,15]$.

\section{Experimental part}

The three main groups of compositions are based on: - constant bimodal ratio of ammonium perchlorate and - constant polybutadiene/dyisocyanate $\mathrm{NCO} / \mathrm{OH}$ ratio and have been prepared for this research [7]:

I the "empty" one i.e. referent formulation,

II the "unstabilized" and

III the "stabilized" formulations.

The contents of RDX are varied at two levels in stabilized and unstabilized batches, and shown in Table 3.

Table 3. Prepared propellant compositions

\begin{tabular}{|c|c|c|c|c||}
\hline No & $\begin{array}{c}\text { AP-200 } \\
{[\text { mas.\% }}\end{array}$ & $\begin{array}{c}\mathrm{AP}-7 \\
{[\mathrm{mas} . \%]}\end{array}$ & $\begin{array}{c}\mathrm{RDX} \\
{[\mathrm{mas} . \%]}\end{array}$ & $\begin{array}{c}\mathrm{TiO}_{2} \\
{[\mathrm{mas} . \%]}\end{array}$ \\
\hline \hline 0 & 52 & 28 & - & - \\
\hline 76 & 42.25 & 22.75 & 15 & - \\
\hline 77 & 35.75 & 19.25 & 25 & - \\
\hline 13 & 42.25 & 22.75 & 15 & 2 \\
\hline 15 & 35.75 & 19.25 & 25 & 2.5 \\
\hline
\end{tabular}

The propellant binder matrix has been based on hydroxylterminated polybutadiene (HTPB) as prepolymer, commercially named R-45M (Arco) and isophoronediisocyanate (IPDI) as curing agent, with addition of other standard components such as plasticizer, bonding agent and antioxidant. In all cases:

- bimodal mixture ratio of AP was 65:35 (including the average particle sizes of $200 \mu \mathrm{m}$ and $7 \mu \mathrm{m}$ );

- parts of AP are substituted with RDX; 
- used RDX was fraction 100 - $200 \mu \mathrm{m}$, manufacturer Prva Iskra Barič, Fig.4;

- total (AP+RDX) solid phase was 80 mas.\%.

The average particle diameter value of fine fraction of AP is measured by Fischer subsieve sizer (FPA), shown in Fig. 5, and fine AP powder, obtained by grinding the coarse $200 \mu \mathrm{m}$ powder in Hammer mill ACM-10, and has the average size of about $7 \mu \mathrm{m}$, seen in Fig.6. [7].

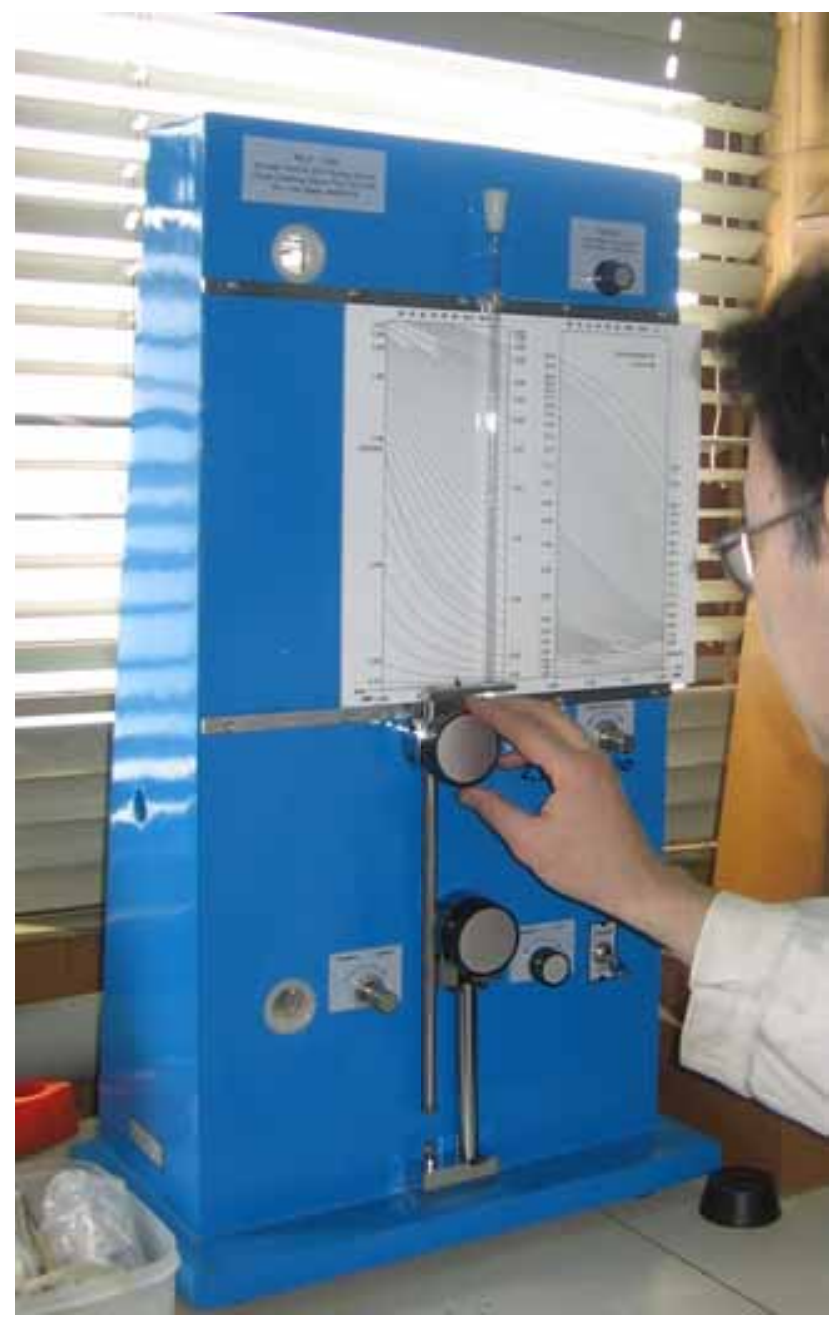

Figure 5. Fisher Subsieve Sizer

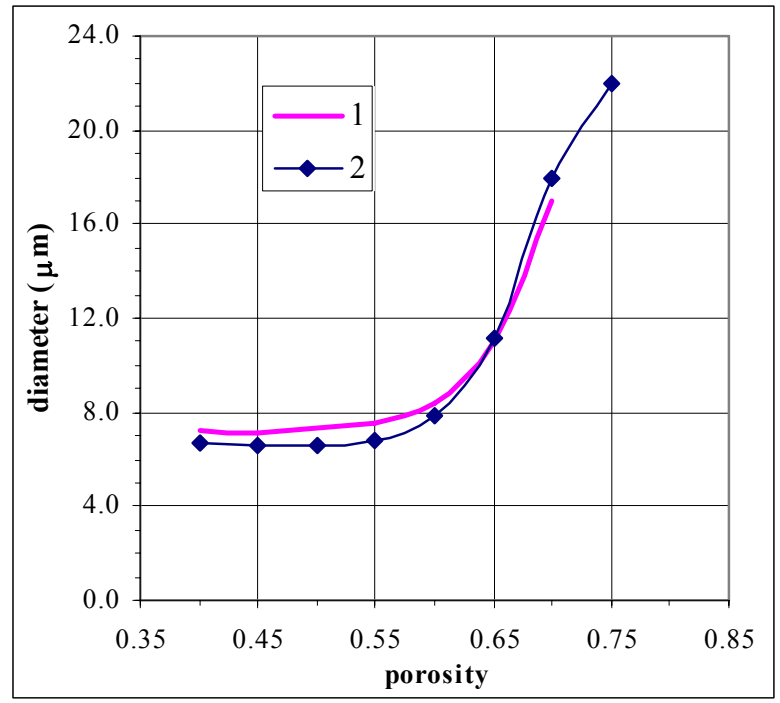

Figure 6. A diameter-porosity plot derived from FPA
All ingredients have been homogenized at $60^{\circ} \mathrm{C}$ in the laboratory vertical planetary mixer, according to applied procedure. A pale yellow appearance of uncured propellant in the mixing bowl is given in Fig.7.

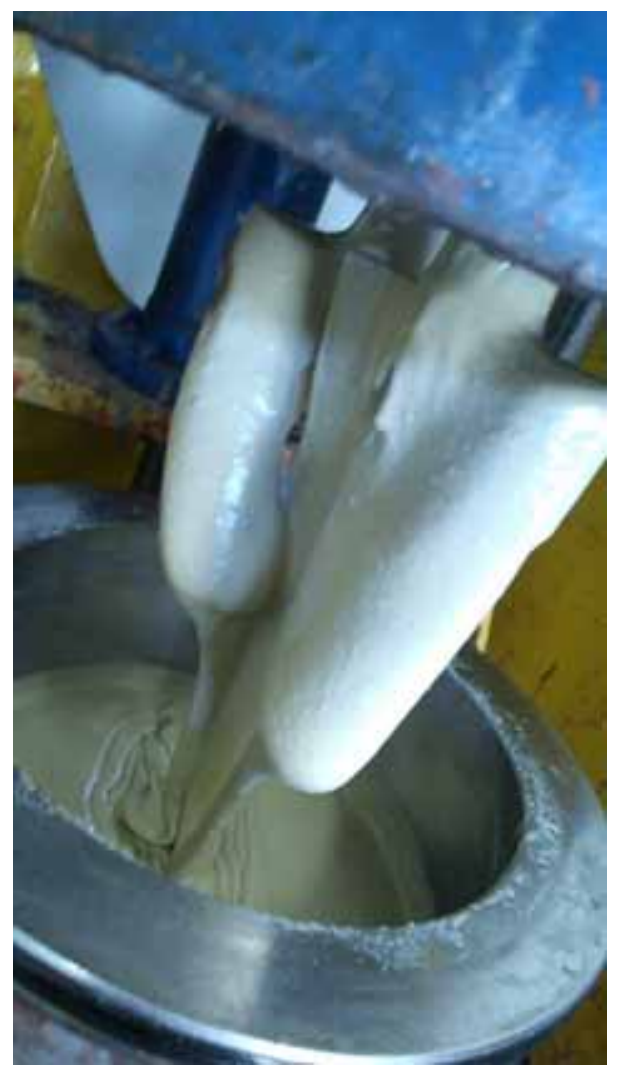

Figure 7. Uncured propellant on mixing blades at the end of homogenizing process

The cast 2-inch chambers of experimental motor (made of PVC), that are used for static tests after curing process and the cardboard box as a mould for the other determinations are shown in Fig.8.

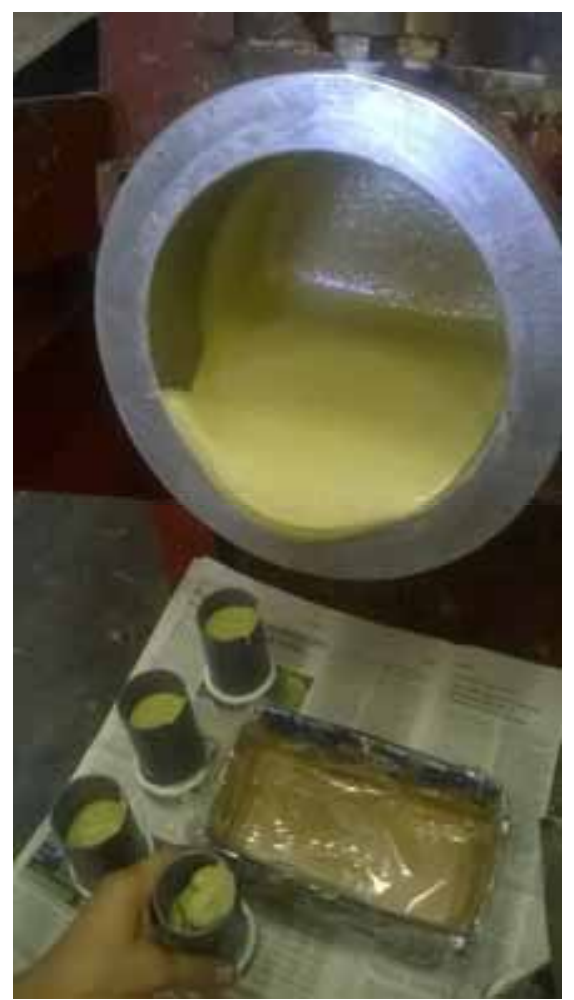

Figure 8. Casting of 2-inch motor case 
After inserting the mandrel, the propellant grains for 2-inch motors (and other samples) were placed in the oven where they were cured at $(70 \pm 2)^{\circ} \mathrm{C}$ for 5 days. Afterwards, when the ambient environment was reached, the grains were delaborated from the tools and laborated at testing motors. After changing the set of nozzles, at any specified test temperature, and applying the igniter, examinations may begin.

Prior to casting all the predicted samples, a small part of uncured propellant was sampled from the mixer, in order to measure the apparent viscosity values. From the very beginning of curing time, the values have been read out from Brookfield HBT viscosymeter scale, at $(60 \pm 2)^{\circ} \mathrm{C}$ every 15 minutes.

Cured blocks of RDX propellant are given in Fig.9.

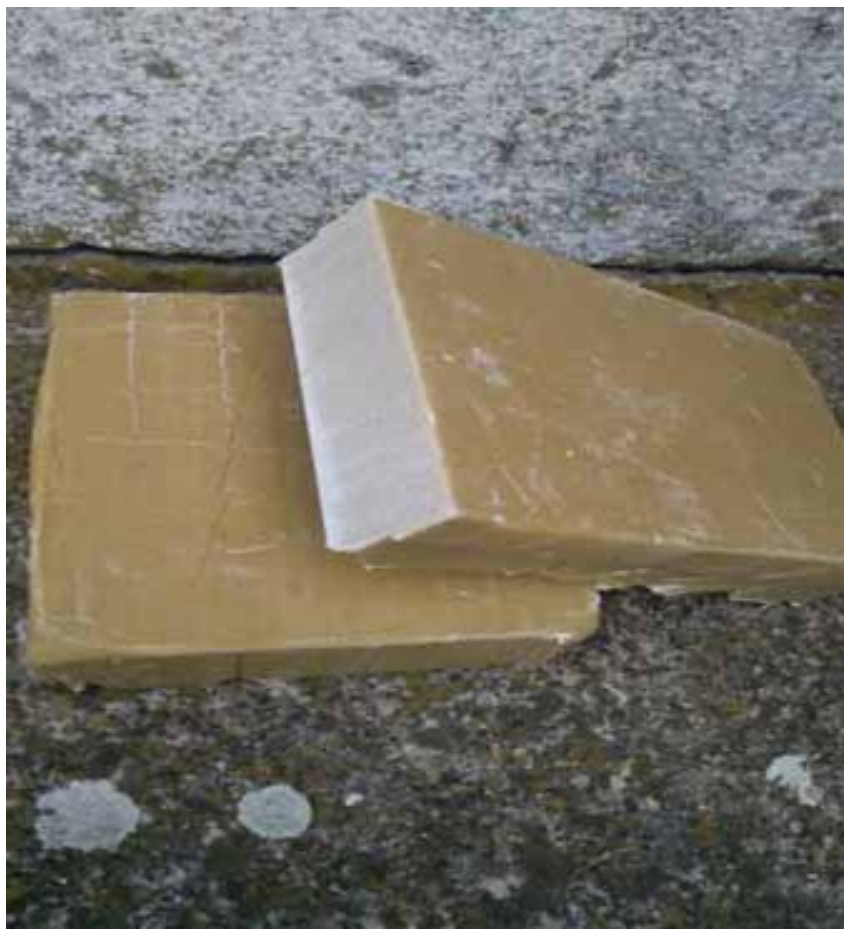

Figure 9. Cured blocks of propellant with RDX

\section{Results of examinations}

The results of viscosity measurements during prolonged period of time are shown in Table 4.

Table 4. Viscosity values of the propellants vs. time

\begin{tabular}{|c|c|c|c|c|c|c||}
\hline \multirow{2}{*}{ No } & \multicolumn{7}{|c||}{ Viscosity (Pa s) vs. time (min) } \\
\cline { 2 - 7 } & 15 & 30 & 45 & 60 & 75 & 90 \\
\hline \hline 0 & 97.6 & 102.4 & 129.6 & 147.2 & 184.0 & 216.0 \\
\hline 76 & 83.2 & 115.2 & 142.4 & 166.4 & 192 & \\
\hline 77 & 96 & 128 & 150.4 & 182.4 & 208 & \\
\hline 13 & 131.2 & 144 & 160 & 184 & 222.4 & \\
\hline 15 & 179.2 & 204.8 & 224 & 264 & 288 & 342.4 \\
\hline
\end{tabular}

The results of burning rate law parameters examination at $20^{\circ} \mathrm{C}$ are given in Table 5: burning rate values at 70 bar $\left(v_{70}\right)$, pressure exponents $(n)$ and constants $(B)$ from the equation linking the burning rate parameters [1].

$$
\nu=B \times p^{n}
$$

where $p$ is the operating pressure in the motor chamber.
Table 5. Burning rate law parameters at $20^{\circ} \mathrm{C}$

\begin{tabular}{|c|c|c|c||}
\hline No & $v_{70}(\mathrm{~mm} / \mathrm{s})$ & $n$ & $B$ \\
\hline \hline 0 & 6.67 & 0.2534 & 2.2743 \\
\hline 76 & 6.28 & 0.2816 & 1.8994 \\
\hline 77 & 5.68 & 0.2983 & 1.6003 \\
\hline 13 & 6.69 & 0.3454 & 1.5417 \\
\hline 15 & 6.28 & 0.3605 & 1.3584 \\
\hline
\end{tabular}

A method for calculating theoretical energetic performances of a composite propellant was investigated. This method, applied as a computer programme, is based on generally accepted hypotheses, simple calculation of the chemical equilibrium in a predominantly gaseous, multicomponent reactive mixture, and an appropriate numerical scheme involving the propellant formula and the assigned rocket motor operating conditions.

Data concerning specific impulses are only comparable if they refer to the same working pressure in the combustion chamber; a frequently employed standard value is 70 bar. Our calculation of the propellant performance data is carried out in the burning process in the rocket chamber which proceeds at constant pressure.

In order to calculate the composition of the products of explosive decomposition, first of all, it is necessary to determine the elementary composition of propellant.

In order to determine the number of moles of combustion products, besides the equilibrium reaction, various dissociation reactions in the chemical balance are also considered. In this way, the concentrations of the combustion products can be obtained by solving a system of equations and using the equilibrium constants.

The combustion temperature is the maximum temperature achieved by combustion products in the zone of intense chemical reactions, during the attainment of the chemical and thermodynamic equilibrium.

Since combustion occurs at a constant pressure, the combustion temperature $T_{c}$ is determined based on the fact that the heat of formation of the combustion products is equal to the standard heat of the propellant formation. Therefore, the first step is to calculate the temperature $T_{c}$ and the composition of the reaction gases (mole numbers $\mathrm{n}$, etc.). The heat of the formation of the combustion products at the $T_{c}$ is equal to the sum of the standard heat of formation and change of the enthalpy from the standard temperature to the $T_{c}$.

For the evaluation of the heat of reaction, the difference of the enthalpies of formation was used; for the internal heat capacities, the corresponding enthalpy values were used from the literature [4]; they are based on the average specific heats $c_{p}$.

Table 6. Some values of thermochemical calculation for three different compositions $(0,77$ and 15$)$

\begin{tabular}{|c|c|c|c|}
\hline Characteristics & 0 & 77 & 15 \\
\hline \hline Enthalpy of formation (J/g) & -2114.09 & -1405.44 & -1686.81 \\
\hline Oxygen balance (\%) & -33.874 & -47.791 & -39.154 \\
\hline Combustion pressure (bar) & 70 & 70 & 70 \\
\hline Heat of explosion (J/g) & 4089.307 & 3529.949 & 3701.625 \\
\hline $\begin{array}{c}\text { Combustion temperature in the } \\
\text { chamber (K) }\end{array}$ & 2375.34 & 2117.863 & 2198.821 \\
\hline $\begin{array}{c}\text { Heat capacity (J/gK) } \\
\text { the nozzle exit (kg/mol) }\end{array}$ & 1.987 & 1.947 & 1.904 \\
\hline Characteristic velocity (m/s) & 1440.67 & 1404.386 & 1390.256 \\
\hline Thrust coefficient, & 1.57 & 1.561 & 1.566 \\
\hline Nozzle area ratio, & 8.116 & 7.842 & 8.017 \\
\hline Specific impulse (Ns/kg) & 2262.33 & 2191.938 & 2177.825 \\
\hline \hline
\end{tabular}


By using a self-devised computer programme, such analyses provide theoretical values of thermochemical characteristics the following parameters were calculated, and some results are presented in Table 6. They correspond to equilibrium performances at the exit of the chamber. These theoretical energetic performances characterize the considered propellants. These characteristics are determined for three compositions: for "empty" one (0), RDX (77), and so called RDX-s (15), i.e. propellants including 25 mas.\% RDX.

\section{Discussion}

These formulations are the preliminary examinations of substitution possibilities between AP and RDX. The changes of viscosity values at mixing temperature and burning rate laws at ambient temperature will be graphically presented and compared for all compositions.

The ,pot life“ of RDX propellants as viscosity changes during the curing time, is shown in Figures 10 and 11, based on Table 4.

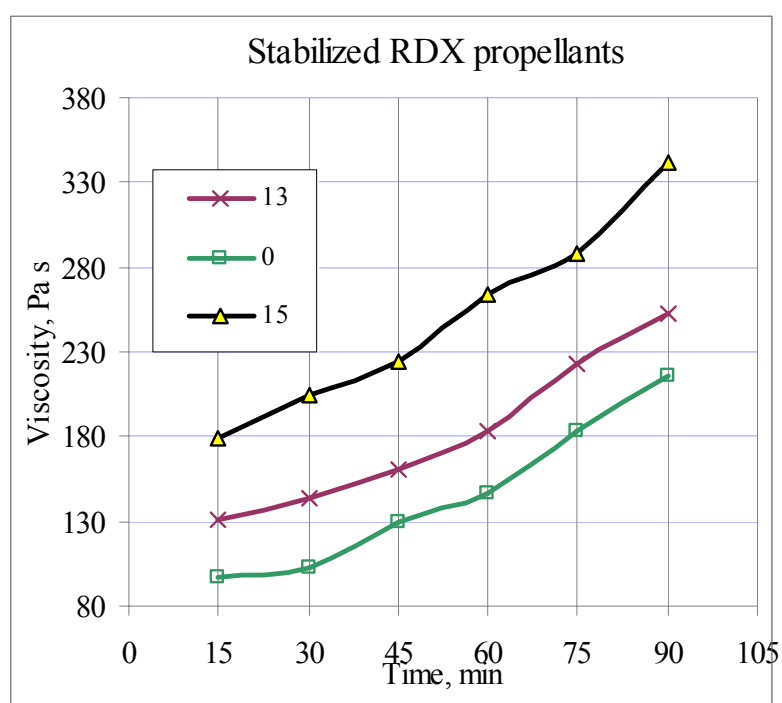

Figure 10. Viscosity changes at $60^{\circ} \mathrm{C}$ for stabilized RDX propellants

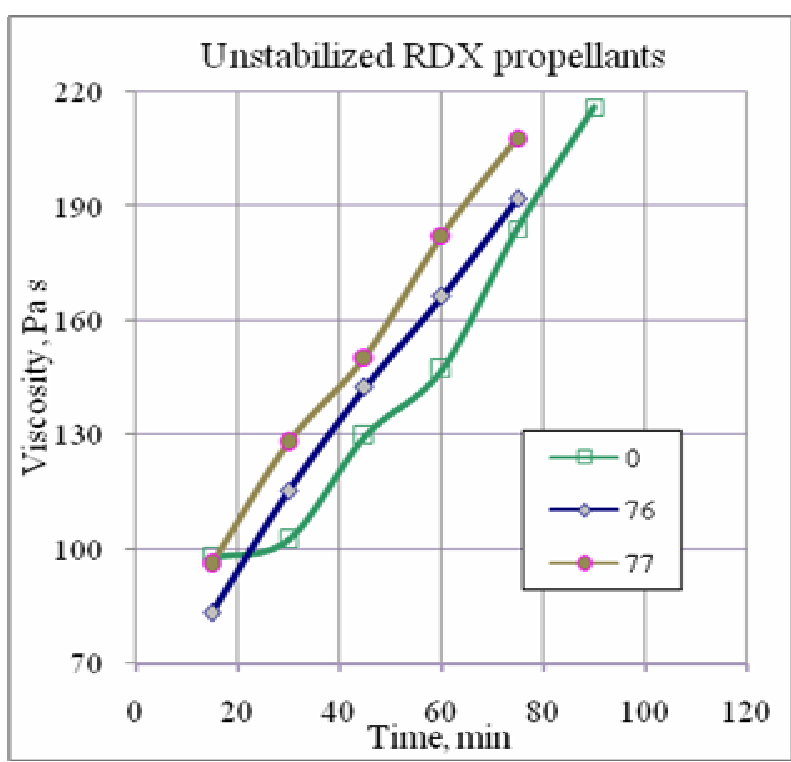

Figure 11. Viscosity changes at $60^{\circ} \mathrm{C}$ for unstabilized RDX propellants

The entering of RDX instead of AP has some negative effects on viscosity values. The molecule of RDX affects the prominent steric hindrances more than a compound of AP. Moreover, adding the other solid ingredient leads to significantly larger differences between those propellants, because of the consequences of total solid phase increase by adding the $\mathrm{TiO}_{2}$ in stabilized types, shown in Fig. 10 .

Parameters of burning rate law are presented in two graphics: for the unstabilized and stabilized nitramine propellants, that each relates to the RDX content level, as shown in Figures 12 and 13.

Generally, burning rates decrease by substituting AP with RDX compound, as shown in Fig.12, and it is a very interesting phenomenon, that the used stabilizer increases the burning rates [7]. But, unlike the previous research with HMX, as it is seen in Fig.13, this is not applicable for the whole range of operating pressures i.e. the higher content of RDX has the same effect on the intersection pressure value of curves ("0" and stabilized one). In the given case, for No 13 ( 15 mas.\% RDX) intersection point is at 65 bar, and for No 15 (25 mas.\%), considered point is at 125 bar.

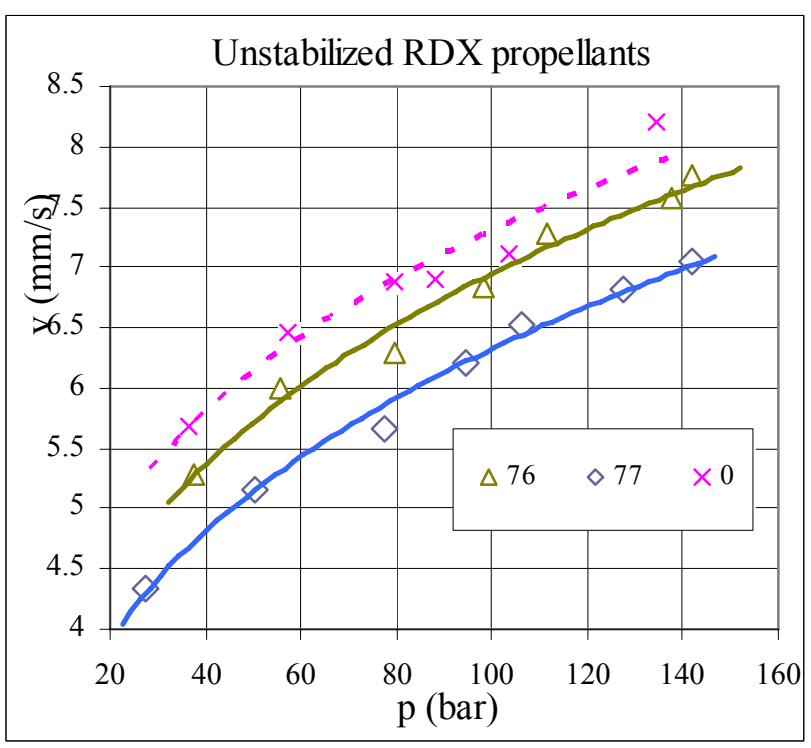

Figure 12. Burning rate laws for unstabilized propellants

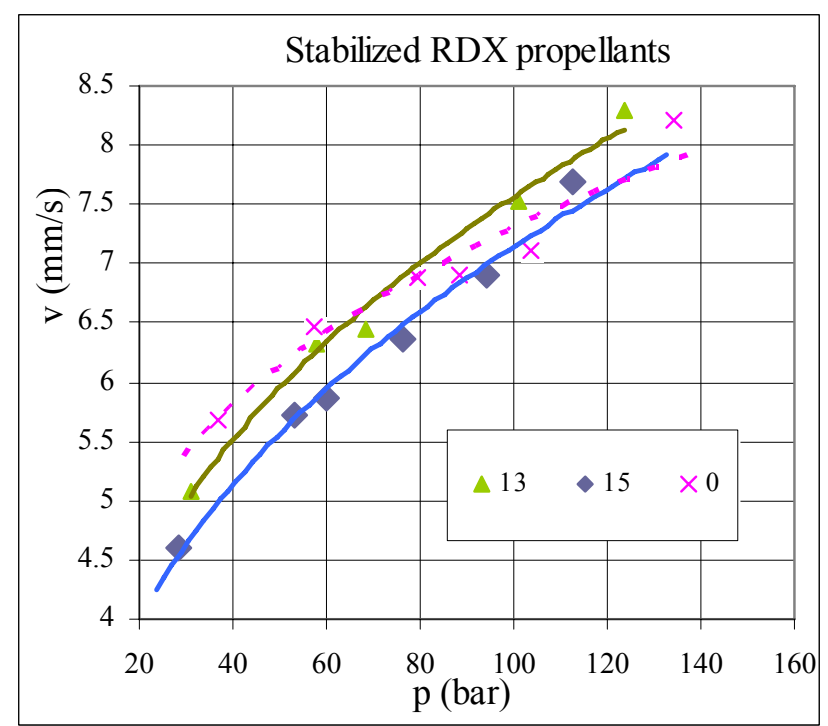

Figure 13. Burning rate laws for stabilized propellants

It looks like the slopes of curves for unstabilized nitramine propellants are parallel i.e. the distances from upper and lower values (for the 15 mas. $\%$ and 25 mas. \%) are unchanged at any value of $\mathrm{x}$-axis, as shown in Fig.12. The same situation can be seen in Fig.13 for two stabilized propellants, (and in Table 5). Although it is very clear that the slopes for 
stabilized compositions are higher, in relation to the referent curve, it could be said that this is the reason for the increase in burning rate values.

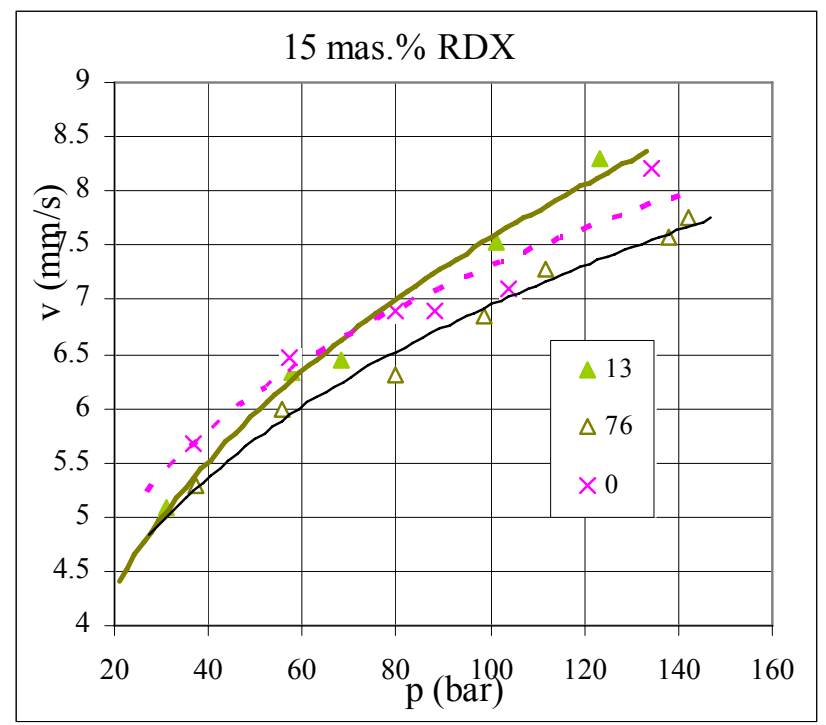

Figure 14. Burning rate laws for 15 mas.\% RDX propellants

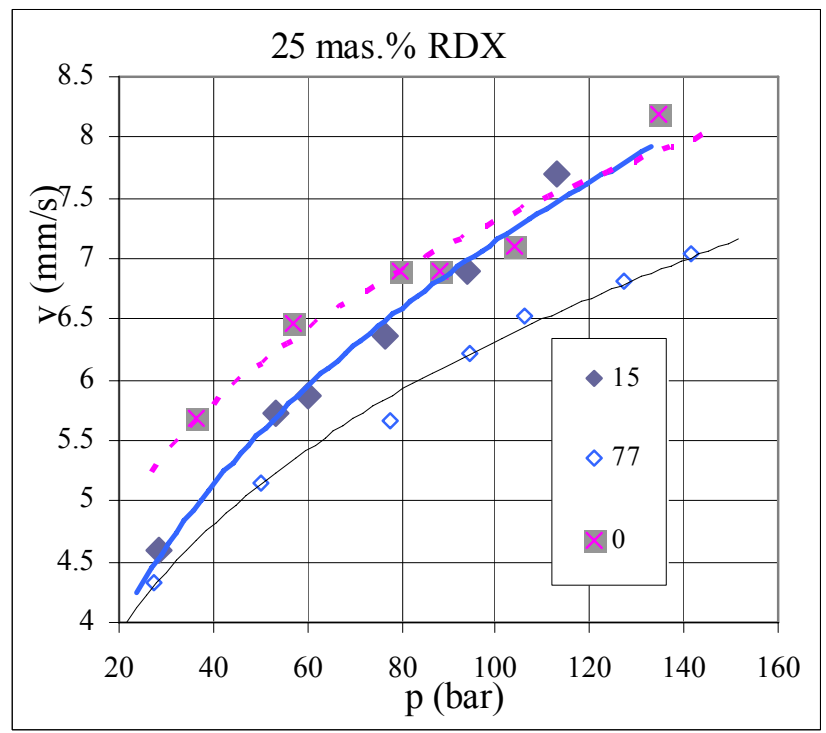

Figure 15. Burning rate laws for 25 mas.\% RDX propellants

Mutual relation among stabilized, unstabilized and empty formulations for the two different content of RDX (15 mas.\% and 25 mas.\%) is shown in Figures 14 and 15.

From the both graphs, it can be noticed that the adding of the stabilizer increases the burning rates via higher pressure exponents, and there are no parallel translations of the curve towards the higher rates, as is the case in the empty one (" $0 ")$. However, higher values of rates than those of the referent propellant could be achieved above different pressures, as it has already been said, above 65 bar (15 mas.\%) and 125 bar (25 mas.\%).

It means that higher contents of RDX in composite rocket propellants are very unfavourable. Besides that, it was noticed that there is some instability at higher pressures: the higher the RDX content was, the lower was the pressure at which the instability point occurred.

The appearances of combustion instability are shown in the following graphs in Figures 16 and 17.

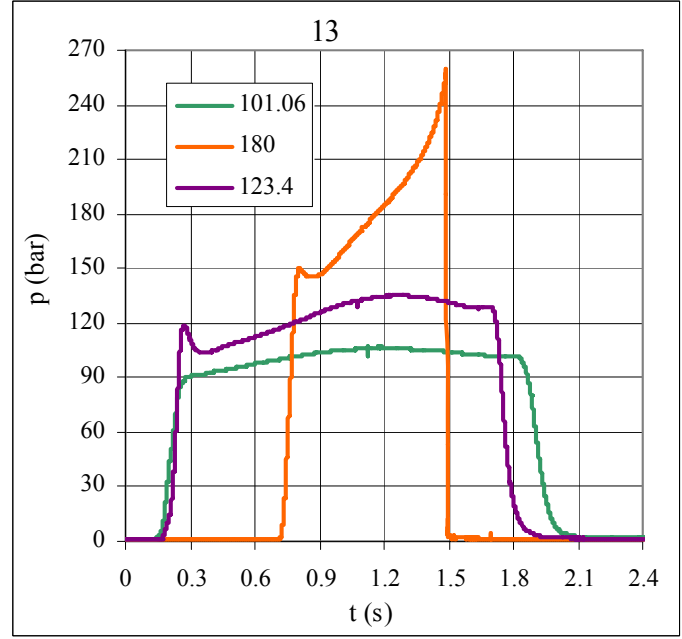

Figure 16. $p=f(t)$ dependencies for No13

In Fig.16 are shown the last three measurements and corresponding average pressures in $p=f(t)$ diagram. A large instability occurred at about 180 bar.

In Fig. 17 the same graphs are shown: the last three measurements and corresponding average pressures in $p=f(t)$ diagram. A somewhat smaller instability of the combustion process occurred at 113 bar (or at some higher values).

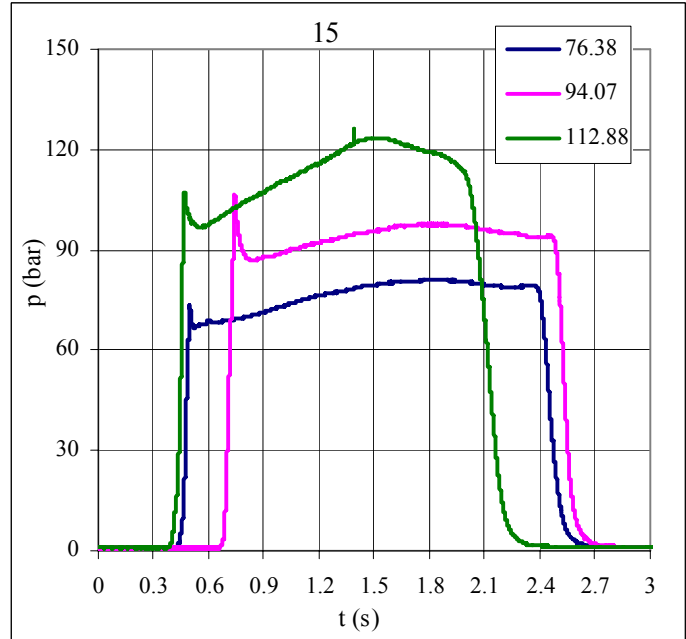

Figure 17. $p=f(t)$ dependencies for No15

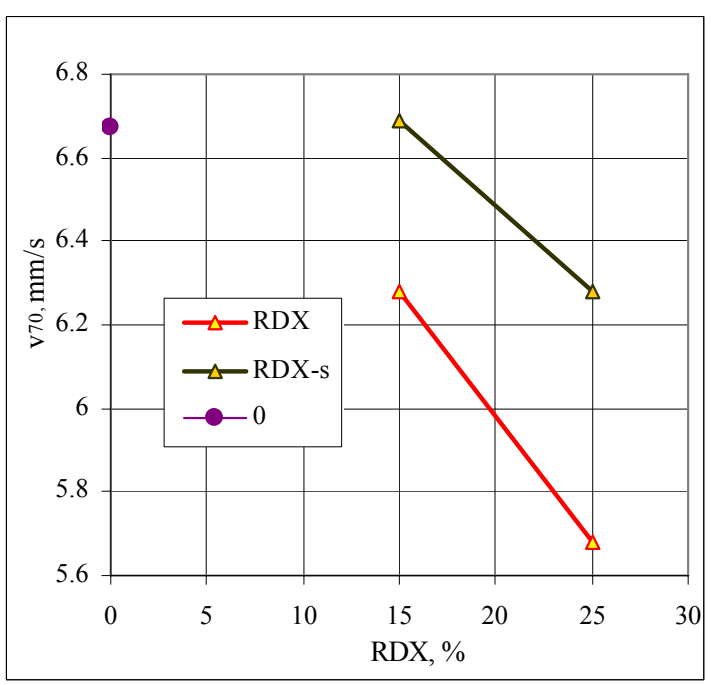

Figure 18. The change of burning rates 
Generally, it is obvious that the instability shifted towards lower pressures by increasing the RDX content, by using the same coarse/fine AP ratio.

In the next figures, roughly said, the shift of the two main parameters of burning rate laws for corresponding propellants is shown: the rates in Fig. 18 and pressure exponents in Fig. 19.

It is clear from Fig.18 that the content of the stabilizer, $\mathrm{TiO}_{2}$, is not enough to increase the burning rate to the referent level ("0"), especially for large contents of RDX. It is important that the drop of burning rate for RDX-s (from 15 to 25 mas.\%) is favourable, and less favourable in case of pressure exponents, because of the increase of the value, as shown in Fig. 19. So, the influence of this additive and content of nitramine on intenal ballistics is obvious.

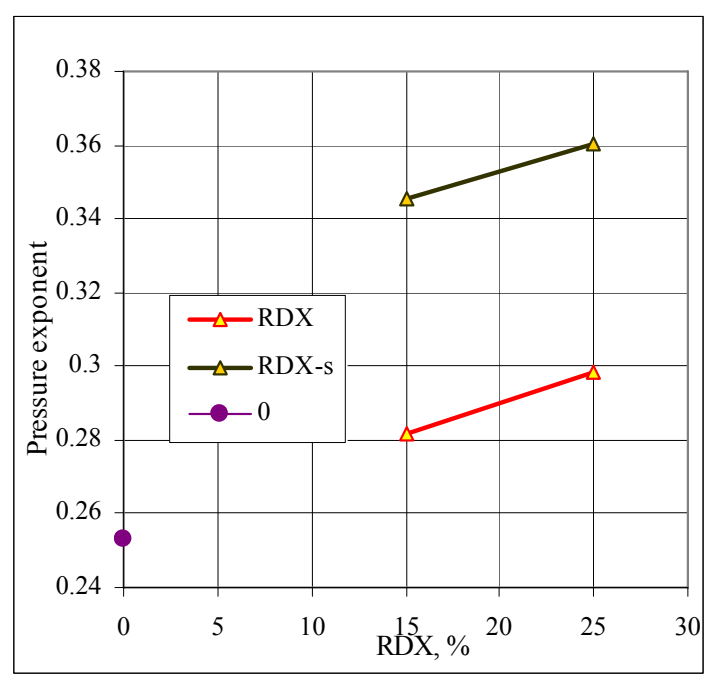

Figure 19. The change of pressure exponents

Any considered substitution between AP and RDX, leads to the change of the burning rate. It is already well known, that the burning rates of nitramine propellants are usually much lower than comparable AP propellants [11]. An explanation for the slight variation in burning rate bellow 200 bar can be found in the fact that nitramine composite propellants, although heterogeneous in physical structure, burn more as a homogeneous propellant [5]. During the burning, the crystalline RDX melts at $205^{\circ} \mathrm{C}$, at times together with the polymeric binder on the propellant burning surface and forms a chemically energetic liquid mixture. Because of this melting, the combustion waves in the gas phase are homogeneous.

In the melt layer of RDX, combustion is expected to be at the distance of about $50 \mu \mathrm{m}$ from the surface. In the case of AP propellants, the ignition temperature is at $377^{\circ} \mathrm{C}$ and the surface temperature in case of full combustion is around 627 $727^{\circ} \mathrm{C}$. When immersed in the inert binder with the surface temperature of about $1027^{\circ} \mathrm{C}$, the AP should reach the combustion as soon as it is uncovered, with no transition delay [11]. All of that is also obvious from the values of constants B from the burning rate laws of all compositions.

Literature data from observing the combustion of nitramine show the discontinuities in the burning rate depending on the pressure, as well as an abrupt change in the burning rate at around 50 bar, where the pressure exponent increases during a narrow pressure range and elevates the burning rate by several orders of magnitude.

One explanation for this burning rate behavior states that the added heat transfer to the larger crystals causes the crystals to crack due to thermal stresses. The cracking increases the exposed crystal surface area. The greater surface area increases the burning rate by allowing even greater heat transfer into the solid. The above explanation indicates that the slope breaks result from structural changes in the RDX crystals, and not changes in the actual burning rate/pressure dependence of pure RDX. Small nitramine particles do not show this behavior and have a much smoother burning rate vs. pressure curve [11]. Used RDX particles are sized from 100 $200 \mu \mathrm{m}$, so there was a real possibility for partial realisation of appearance of crystal cracking to an unknown extent, bearing in mind the introductory remark that AP consists of the same coarse/fine particles ratio, as the most favorable ratio for bimodal mixture, when it comes to combustion stability [17]. Adding of RDX shows acceptable values of pressure exponent, but only up to 150 bar. The effect of titania compound was shown as very significant, but it would be useful to apply other recommended suplements (copper (II) phtalocyanine, copper (II) sulphide) intented for the stabilization of nitramine propellants.

On the other hand, considering determined thermochemical properties from Table 6 , it could be said that these parameters are functions of the propellant composition and chamber pressure. A specific impulse can also be computed for a particular nozzle configuration and the value of specific impulse is high if the reaction heat is high and produces a high flame temperature, and if the average molecular weight of the reaction products is low [2].

These theoretical thermodynamic performances of a propellant are useful as a means for evaluating and comparing the performances of various rocket systems; all calculations, depending on input accuracy, present the prediction of the operational performance of any rocket unit, and the determination of several important design parameters for any given performance requirement. A programme like this should be capable of obtaining equilibrium compositions for assigned thermodynamic states: the temperature and pressure, enthalpy and pressure, and entropy and pressure, and be capable of performing calculations of theoretical energetic performances of composite propellants, with high convergence rate [16].

It is very interesting to determine all molecules, groups and radicals that are formed during combustion. Accuracy and reliability of presence and quantity of content in percentages is very important when it comes to setting up the correct initial situation. For example, the mol. \% of presumed chemical groups present at combustion chamber, at the nozzle and at the exit for the "empty" propellant - without RDX are given in Fig.20, in Fig. 21 for CSP with 25 mas.\% RDX and in Fig. 22 for CSP with 25 mas.\% RDX and 2.5 mas. $\% \mathrm{TiO}_{2}$.

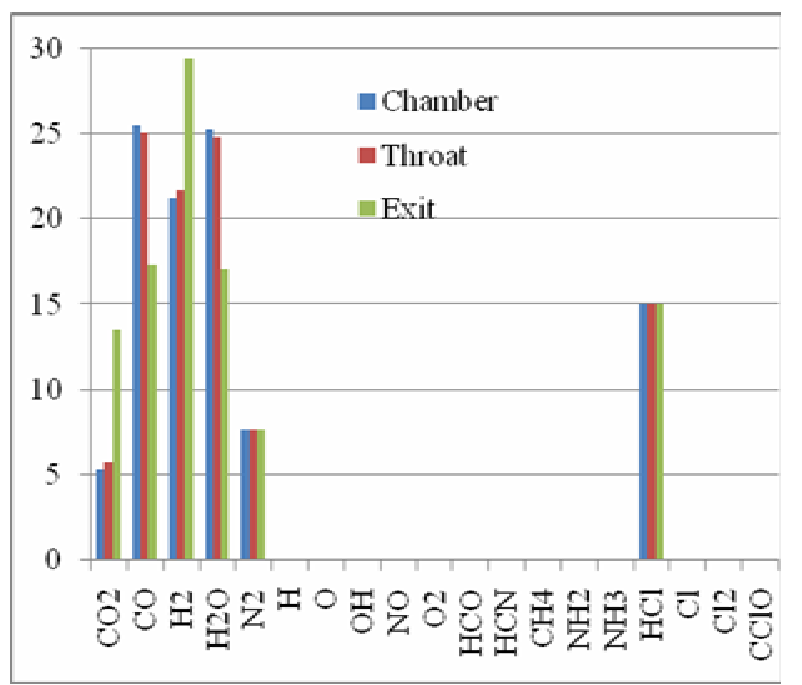

Figure 20. Combustion product mixture for "0" CSP 
Considering thermochemical characteristics from Table 6 , it is obvious that it would not be possible to make conclusions about the benefits of the ingredients that were considered. This particularly relates to the values of specific impulse. The main faults of all calculations are the presumptions that we applied [16]. Other reasons are the consequences of the lack of imperfect self-designed programme which is new and needs many improvements for example by using a better simulations of combustion process of the raw materials data.

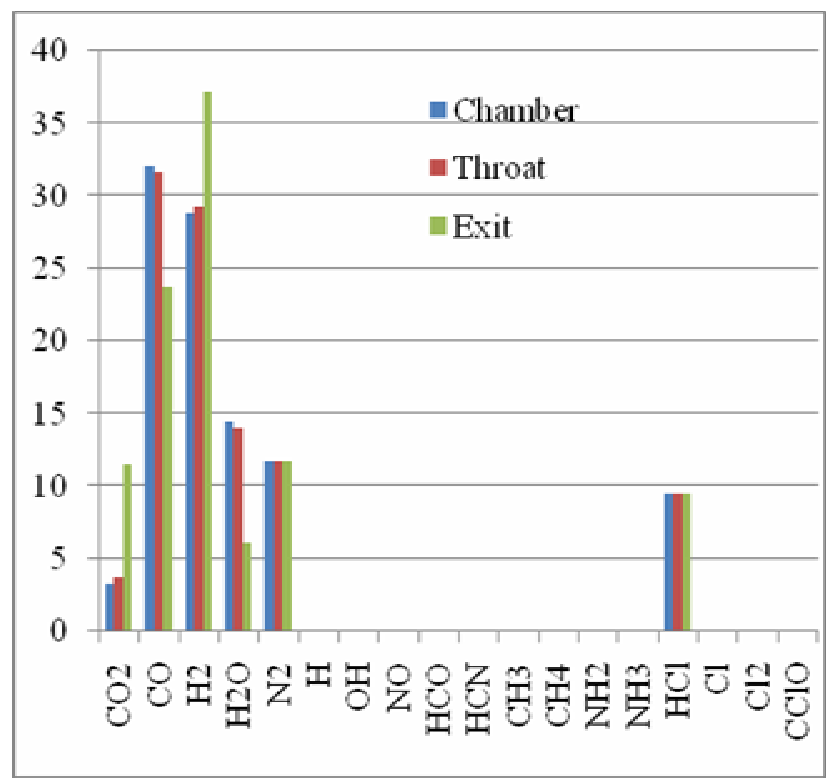

Figure 21. Combustion product mixture for 25 mas.\% RDX in CSP

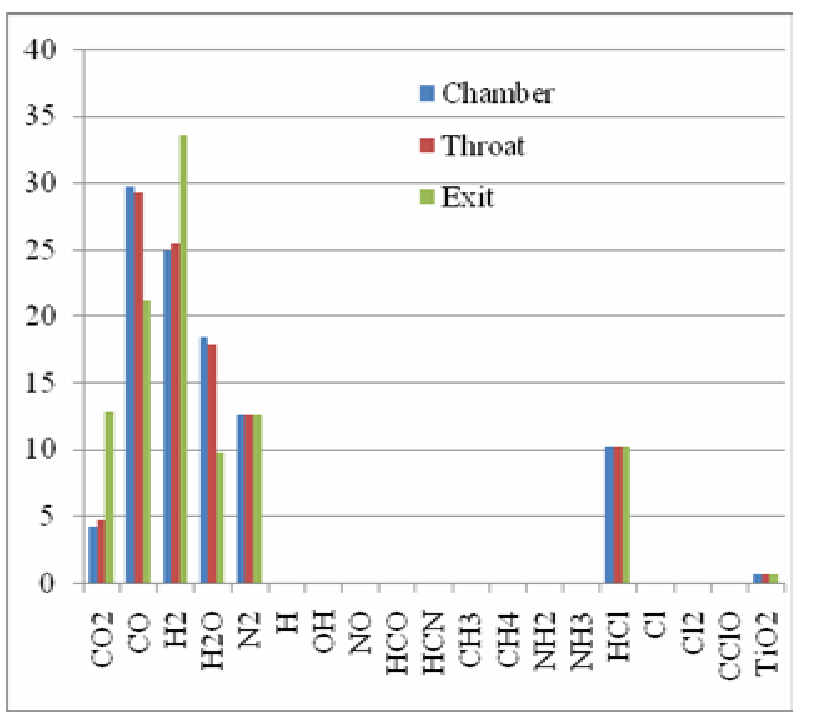

Figure 22. Combustion product mixture for 25 mas.\% RDX and 2.5 mas.\% $\mathrm{TiO}_{2}$. in CSP

However, it is useful for considering the changes among the compositions of interest. The problem is also the deficit of oxygen which is present in all calculations and it is dependent on the proposed characteristics of the used prepolymer.

In addition, in future calculations, enhancements would be necessary, especially in case of metalized CSP which should show higher specific impulse. The problem of those metal CSP lies in the fact that metal oxides are liquid and established equations and approximations are not valid. However, it would be interesting to analyse hypothetical composition of nitramine propellants with some different metal fuel (aluminium, magnesium, boron) to predict the change of specific impulse if the purpose of that research is the range of the propellant [3].

\section{Conclusion}

Research presented in this paper gives the preliminary results of the applied replacement of the oxidizer by an explosive, through development of composite solid propellants based on ammonium-perchlorate (AP) and formulations with two levels of hexogen (RDX). The binder was based on hydroxyl-terminated polybutadiene prepolymer and isophorone-diisocyanate as a curing agent.

The five compositions were prepared; in two of them titanium (IV) oxide was added as a combustion stabilizer. 80 mas. $\%$ of bimodal AP mixture $(200 \mu \mathrm{m}$ and $7 \mu \mathrm{m}$ in ratio 65/35) was the basic solid phase: the substitution with RDX was done at two levels 15 mas. $\%$ and 25 mas. $\%$ while AP remained at the same ratio. RDX particles were $100-200 \mu \mathrm{m}$. The fifth composition was the referent one without RDX.

The ,pot life" i.e. the change of viscosity values at mixing temperature and burning rate law parameters at $20^{\circ} \mathrm{C}$ was discussed in this article.

The entering of RDX instead of AP had some negative effects on viscosity values. The molecule of RDX affects the prominent steric hindrances more than AP.

Burning rates decreased by substituting AP with RDX compound, and it is a very interesting phenomenon, that the used stabilizer $\mathrm{TiO}_{2}$ increased the burning rates. However, unlike the previous research with HMX, this was not applicable for the whole range of operating pressures. In the given case, for No 13 (15 mas.\% RDX) above 65 bar, and for No 15 (25 mas.\%), above 125 bar, the burning rate of RDX stabilized propellants was higher than for AP propellant ("0"). As the content of RDX became larger, higher pressure was needed for equalization and enhancement of the burning rates.

The burning rate-pressure slopes, (i.e. pressure exponents) of curves for unstabilized nitramine propellants were parallel, as were the curves for two stabilized propellants. The slopes for stabilized compositions were higher in relation to the referent curve, so it could be said that it was the reason for the increase in burning rate values. The adding of the stabilizer increased the burning rates via higher pressure exponents, and there were no parallel translations of the curve towards the higher rates, as was the case in the empty one ("0"). However, higher values of rates than those of the referent propellant could be achieved, as it has already been said, above the pressures of 65 bar (15 mas.\%) and 125 bar (25 mas.\%).

This appearance was, most likely, the consequence of heat feedback from the flame to the burning surface that caused the crystal to crack; RDX particles were between 100 - $200 \mu \mathrm{m}$, so indeed this phenomenon might be expressed in the case of larger particle sizes.

It was noticed that higher contents of RDX in composite rocket propellants were very unfavourable, because of the appearance of instability at higher pressures: the higher the RDX content was, the lower was the pressure at which instability occurred. It would be interesting to reduce this occurrence by distributing the solid phase differently, so that the RDX particles are a part of coarse AP, while preserving the content of the fine portion and achieving the best packaging in some future research. The effect of titania compound was shown as very significant, but it would be recommended to apply other additives with the same or similar influence (copper (II) phtalocyanine, copper (II) sulphide) which is intended for the stabilization of nitramine propellants.

The adding of RDX showed more than acceptable value of pressure exponent, lower than 0.3 , but the presence of titania compound increased it. Further research would be necessary to achieve better results. 
It is possible to control the ballistic behaviour of the propellant by selecting varied formulation parameters. The slopes and burn rates can be tailored via formula modification. Additionally, changes in selection of the curative and particle size of the ballistic modifier could produce slopes at different burn rates and pressure region [18].

This type of high energy propellants could find applications in missiles and rockets where thermal and pressurization loads are predominant, such as tactical and strategic missiles [8].

It is important to say that composite propellants based on nitramines are being used more and more. Without aluminium as additive, they belong to the minimum smoke category and they replace DB propellants. With aluminium as additive, they reach the highest specific impulse and density and are used for upper stages of strategic missiles [11]. Calculated thermochemical characteristics are very dependent on presumptions that were used in these determinations. In addition, there are many other software, but each of them inevitably makes a mistake, as they are a consequence of approximations.

Enhancement of the self-devised programme would lead to more accurate determination of thermochemical characteristics of solid propellants. Along with other examinations of the combustion behaviour of nitramines, this would enable the estimation of the characteristics of CSP with metal fuel in the matrix, since they generate superior performances to those that lack metal fuel [3].

\section{Literature}

[1] TERZIĆ,J LEKIĆ,A ZEČEVIĆ,B. Prediction the Theoretical Interior Ballistic Properties of Solid Propellant Rocket Motors, $6^{\text {th }}$ Seminar "New Trends in Research of Energetic Materials" University of Pardubice, 23-25. April 2003, ISBN 0-7194-543-9, pp.420-435.

[2] VENKATACHALAM,S., SANTHOSH,G., NINAN,K.N.: High Energy Oxidisers for Advanced Solid Propellants and Explosives, Chapter 1 Introduction to Explosives and Propellants Advances in Solid Propellant Technology, P1 International HEMS1 Workshop, Ranchi, INDIA, 2002, pp.87-106.

[3] FIGUEIREDO,P.A., BROJO,F.M.: Theoretical analysis of ammoniumperchlorate based composite propellants containing small size particles of boron, 4th International Conference on Energy and Environment Research, ICEER 2017, 17-20. July 2017, Porto, PORTUGAL

[4] KUBOTA,N.: Combustion of Composite Propellants: Combustion of Composite Propellants, in Propellants and Explosives,
Thermochemical Aspects of Combustion, Wiley-VCH Verlag GmbH \& Co. KGaA, Weinheim, GERMAMY. doi: 10.1002/9783527693481.ch7, 2015.

[5] BeCKSTEAD,M.: Recent Progress in Modeling Solid Propellant Combustion, Combustion, Explosion and Shock Waves, November 2006, Vol.42, No.6, pp.623-641

[6] MEYER,R., KÖHLER,J., HOMBURG,A.: Explosives. Wiley- $V C H$, Verlag, GmbH \& Co. KG aA, Fifth Edition, 2002.

[7] RODIĆ,V., BOGOSAVLJEVIĆ,M., MILOJKOVIĆ,A., BRZIĆ,S., FIDANOVSKI,B., GLIGORIJEVIĆ,N.: Preliminary Research of Composite Rocket Propellants Including Octogene, Scientific Technical Review, ISSN 1820-0206, 2017, Vol.67, No.1, pp.3-12.

[8] BRILL,T.B.: Heat Flow / Chemistry Interface in the Condensed phase $(H M X)$, ONR Workshop on Energetic Material Initiation Fundamentals, Livermore, Cal., December 1988.

[9] KUBOTA,N.: Combustion Mechanisms of Nitramine Composite Propellants, Symposium (International) on Combustion 18(1):187-194 December 1981. DOI: 10.1016/S0082-0784(81)80023-9

[10] Behera, S. Effect of RDX on Elongation Properties of AP/HTPB Based Case Bonded Composite propellants, DRDO Science Spectrum, March 2009, pp. 31-36.

[11] LENGELLÉ,G., DUTERQUE,J., TRUBERT,J.F.: Combustion of Solid Propellants, RTO/VKI Special Course on "Internal Aerodynamics in Solid Rocket Propulsion", held in Rhode-Saint-Genèse, BELGIUM, 27-31. May 2002, Published in RTO-EN-023, pp.43-58.

[12] RODIĆ,V., DIMIĆ,M., BRZIĆ,S., GLIGORIJEVIĆ,N.: Cast Composite Solid Propellants with Different Combustion Stabilizers, Scientific Technical Review, ISSN 1820-0206, 2015, Vol.65, No.2, pp.3-10.

[13] TAYLOR,R.: Controlled Burn Rate, Reduced Smoke, Solid Propellant Formulations, US Patent 5,334,270, 1994.

[14] RODIĆ,V.: The effect of titanium (IV) oxide on burning stability of composite solid propellants, $4^{\text {th }}$ International Scientific Conference OTEH 2011,06-07. October 2011, Belgrade, SERBIA, ISBN 978-8681123-50-8, pp.354-360.

[15] RODIĆ,V.: Effect of titanium (IV) oxide on composite solid propellant properties, Scientific Technical Review, ISSN 1820-0206, 2012, Vol.62, No.3-4, pp.21-27.

[16] FILIPOVIĆ, M., KILIBARDA,N.: The Calculation of Theoretical Energetic Performances of Composite Rocket Propellants, J. Serb. Chem. Soc., 2001, 66 (2), pp.107-117.

[17] RODIĆ,V., FIDANOVSKI,B.: Burning Stability of Composite Solid Propellants Including Zirconium Carbide, Scienticif Technical Review, ISSN 1820-0206, 2013, Vol.63, No.3, pp.33-40.

[18] CHAN,M., TURNER,A.: Insensitive High Energy Booster propellant, US Patent, 6,682,614 B1, 2004.

Received: 13.02 .2018 . Accepted: 10.05.2018.

\title{
Preliminarna istraživanja kompozitnih raketnih goriva sa heksogenom i titandioksidom
}

\begin{abstract}
U radu su prikazana istraživanja kompozitnih raketnih goriva na bazi amonijum perhlorata, hidroksiterminiranog polibutadiena i izoforon diizocijanata sa različitim udelima heksogena (RDX). Masa RDX je povećavana na račun oksidatora, konstantnog bimodalnog sastava. Sagorevanje goriva je stabilizovano dodatkom titanijum (IV) oksida. Određivani su parametri zakona brzine sagorevanja i prividnog viskoziteta i poređeni sa vrednostima za goriva istih sastava čvrstih faza. Proračuni termohemijskih parametara takođe su dati u ovom istraživanju.
\end{abstract}

Ključne reči: kompozitno raketno gorivo, amonijum perhlorat, hidroksiterminirani polibutadien, heksogen, titan oksid, balističke karakteristike, termohemijski parametri. 


\title{
Предварительные исследования композитных ракетных топлив с гексогеном и диоксидом титана
}

\begin{abstract}
В работе представлены исследования композитных ракетных топлив на основе перхлората аммония, гидроксилированного полибутадиена и изофорондиизоцианатов с различными фракциями гексогена (RDX). Масса гексогена увеличивается за счёт окислителя, постоянного бимодального состава. Сгорание топлива стабилизируется добавлением оксида титана (IV). Параметры закона скорости сгорания и закона кажущейся вязкости были определены и сопоставлены со значениями для топлив одинакового твёрдофазного состава. Расчёты термохимических параметров также приведены в этом исследовании.
\end{abstract}

Ключевые слова: композитное ракетное топливо, перхлорат аммония, гидроксилированный полибутадиен, гексоген, оксид титана, баллистические характеристики, термохимические параметры.

\section{Recherches préliminaires sur les propergols composites à hexogène et à titane oxyde}

\begin{abstract}
Les recherches sur les propergols composites à la base de l'ammonium perchlorate hydroxyle terminé polybutadiène isophorone diisocyanate avec les différents niveaux de hexogène (RDX) ont été présentées dans cet article. La masse de RDX augmente en relation avec l'oxydant de composition constante bimodale. La combustion du propergol est stabilisée par l'addition de titane oxyde (IV). On a déterminé les paramètres de la loi de vitesse de combustion et de la viscosité apparente et on les a comparés avec les valeurs des propergols de la même composition des phases solides. Les calculs des paramètres thermochimiques ont été présentés aussi dans cette recherche.
\end{abstract}

Mots clés: propergol composite, ammonium perchlorate, polybutadiène hydroxyle terminé, hexogène, titane oxyde, caractéristiques balistiques, paramètres thermochimiques. 